\author{
STUDIA POLONIJNE \\ T. 42 LUBLIN 2021 \\ DOI: $\frac{\text { http://doi.org/10.18290/sp2142.11 }}{10}$
}

STANISŁAW KILIAN

\title{
MOTYW „PEŁNEJ” SUWERENNOŚCI W MYŚLI POLITYCZNEJ EMIGRACYJNEGO STRONNICTWA NARODOWEGO W LATACH 1945-1989
}

W języku publicystyki politycznej emigracji centralne miejsce zajmuje pojęcie „pełna suwerenność”; w pierwszych latach powojennych najczęściej posługiwali się nim uczestnicy dyskusji dotyczącej celów polityki polskiej, w latach siedemdziesiątych ustąpiło miejsca problematyce „demokratyzacji ustroju", powróciło w pierwotnym brzmieniu na początku lat osiemdziesiątych w opisie przemian politycznych w kraju. „Nie podoba mi się wyrażenie petna suwerenność - pisał wówczas Tadeusz Rzewuski [?] - tak jakby istniał obecnie jakiś stopień niepodległości, który trzeba by tylko uzupełnić" ${ }^{1}$. W tym nurcie opinii pojawia się wypowiedź Zygmunta Celichowskiego (Kanada), która podaje w wątpliwość istnienie stanu pełnej suwerenności. „Czy w ogóle są na świecie - pytał - państwa całkowicie suwerenne? Co najmniej wątpliwe [...]. Rosji suwerennej nie ma. Jest ona najsilniejszym partnerem w związku państw, ale nie wszechwładnym"2. Wcześniej podobne pytania formułowali przywódcy stronnictw historycznych, uczestnicy debaty na temat ustroju politycznego „państwa na uchodźstwie” (Londyn, 16 i 19 lipca 1949). Debata ujawniła rozbieżności w ocenie skali niezależności politycznej, tradycyjnie definiowanej suwerenności jako stanu „samowładzy” - niezależności w decydowaniu politycznym i ,jednowładzy" - władztwa konstytucyjnie uprawomocnionego mandatem narodu - wynikającego z zasady

Dr hab. StAniSŁaw KiLIAN, prof. UP - Instytut Nauk o Polityce i Administracji Uniwersytetu Pedagogicznego im. KEN w Krakowie; e-mail: stanislawkilian@wp.pl; ORCID: https://orcid. org/0000-0003-2307-673X.

${ }^{1}$ Archiwum Akt Nowych [dalej: AAN], sygn. 117, Akta S. Łuckiego (nazwisko nieczytelne T. Rzewuski [?]), Uwagi do zarysu zagadnień do dyskusji na VI Centralny Zjazd SN, b. m., 7 VI 1987.

${ }^{2}$ Biblioteka Uniwersytetu Mikołaja Kopernika w Toruniu, Archiwum Emigracji, sygn. L-46, Z. Celichowski, Uwagi na temat przyszłego ustroju państwa polskiego, mps, b. m., lata 80. XX wieku, s. 1. 
legalizmu. „Może to być prawniczą herezją, ale uważam - mówił Stanisław Mikołajczyk - że Państwo Polskie istnieje (choć) okupowane przez Sowiety". Nie przeceniał znaczenia legalizmu jako atutu emigracyjnej władzy, co więcej, opowiada się za zastąpieniem emigracyjnego rządu ,jakąś reprezentacją polską, by mogła ona zajmować stanowisko i działać na gruncie międzynarodowym" - komitetem narodowym ${ }^{3}$. Stanowiska prezesa PSL-u nie podzielili przywódcy stronnictw historycznych Polskiej Partii Socjalistycznej - Adam Ciołkosz i Stronnictwa Narodowego - Tadeusz Bielecki; bronili legalizmu jako fundamentu konstrukcji ustrojowej „państwa na uchodźstwie” i odmawiali uznania dla „uzurpatorskiego" rządu w Warszawie. Na podstawie ważności mandatu politycznego sprzed wojny, odczuwając siłę moralnego upoważnienia narodu, przyznawali sobie prawo określenia celów polityki polskiej - celem głównym miało być odzyskanie „pełnej” suwerenności. O ile pojęcie „suwerenności” wydawało się zrozumiałe, to określenie „pełnej” rodziło pytania; co to oznacza, a dalej, czym wyróżnia się stan „niepełnej suwerenności”. We współczesnych badaniach z obszaru stosunków międzynarodowych w pojęciu niepełnej suwerenności odzwierciedla się stan sformalizowanej kontroli mocarstw wobec kolonii, protektoratów, kondominiów, terytoriów powierniczych ${ }^{4}$. W podobnym duchu pojęciem "kolonia" określili charakter polityki sowieckiej wobec Polski i państw Środkowo-Wschodniej Europy publicyści „Myśli Polskiej” - sztandarowego organu SN.

Celem badawczym artykułu jest ukazanie ideowych i politycznych aspektów pojęcia „pełnej” suwerenności jako głównego motywu „polityki polskiej” emigracyjnego Stronnictwa Narodowego, a także jako czynnika polityzacji grupy narodowców. Wybór SN uzasadnia miejsce, jakie grupa ta zajmowała w życiu politycznym emigracji; nazwiska liderów Stronnictwa pojawiają się w organach władzy „państwa na uchodźstwie” i emigracyjnej dyplomacji. Pozostawili po sobie sporą ilość materiałów, które ilustrują charakter ich politycznej działalności, materiały te stanowią bazę źródłową tego artykułu.

Po wycofaniu przez mocarstwa zachodnie uznania rządu emigracyjnego i słabnięcia argumentu uczestnictwa we „wspólnocie międzynarodowej”, stopniowego zwijania polskich przedstawicielstw dyplomatycznych, jak i pod wpływem narastającej krytyki niedemokratycznego, „sanacyjnego” ustroju politycznego, w środowiskach centrolewicowych pojawiły się pytania doty-

\footnotetext{
${ }^{3}$ Archiwum Stronnictwa Narodowego [dalej: ASN] (obecnie w Muzeum Niepodległości), Protokót z konferencji stronnictw: PPS, PSL i SN, mps, Londyn 16 i 19 lipca 1949, s. 3. Archiwalia wykorzystane w tym artykule w postaci fotokopii, nagrań, fiszek znajdują się w zbiorach autora.

${ }^{4}$ J. Czaputowicz, Suwerenność, Warszawa 2018, s. 282-284.
} 
czące ważności legitymacji politycznej emigracyjnej władzy. Czy w zmienionych uwarunkowaniach geopolitycznych przedwojenny mandat narodu nadal jest aktualny, czy nieliczna grupa uchodźców wojennych posiada upoważnienie do formułowania w imieniu narodu celów polityki polskiej wyrażonych w formule „odzyskania pełnej suwerenności”. Wątpliwości dotyczyły prawno-ustrojowych fundamentów konstrukcji „państwa na uchodźstwie” opartej na Konstytucji kwietniowej. „Dziś w Kraju po 10-ciu latach przekonywał Mikołajczyk - nie można wobec społeczeństwa wystąpić o uznanie, iż rząd czy Rada Jedności [parlament emigracyjny - S.K.] powstają w oparciu o konstytucję z 1935 r." . Plany organizacji życia politycznego na bazie Konstytucji kwietniowej - uzupełniając myśl prezesa PSL, byłyby krokiem wstecz, powrotem do stanu sprzed wojny, który w opinii krajowej nie budził dobrych wspomnień, do którego społeczeństwo w kraju nie chciało wracać. W ogniu krytyki znalazł się skład personalny emigracyjnej władzy; liderzy ugrupowań opozycji antysanacyjnej nie kryli oburzenia, iż godność prezydenta sprawuje August Zaleski, były minister spraw zagranicznych w rządach pomajowych, utożsamiany z ugrupowaniami sanacji. Na tym tle pojawiało się retorycznie ujęte pytanie, czy zadanie przywrócenia pełnej suwerenności można powierzyć politykom sprzyjającym sanacji, obciążanym zarzutem niszczenia opozycji, nieprzygotowania kraju do wojny i klęską wrześniową. Z tego powodu liderzy stronnictw historycznych odmawiali poparcia prezydentury Zaleskiego, wysuwali pod jego adresem żądania demokratyzacji wykonywania Konstytucji kwietniowej, wyznaczenia następcy i ustąpienia $z$ urzędu.

Zarzuty dotyczące Konstytucji i stylu sprawowania funkcji prezydenta nadwyrężały zaufanie do organów „państwa na uchodźstwie” i osłabiały siłę moralnego upoważnienia emigracji do występowania $\mathrm{w}$ imieniu narodu, co źle wróżyło strategii odzyskania pełnej suwerenności. W sporach wśród elit politycznych „polskiego” Londynu nie uczestniczyli szeregowi członkowie stronnictw, zajęci pokonywaniem wyzwań adaptacyjnych do nowego środowiska, rzadko w okresie wyborów angażowali się w życie polityczne, ster polityki emigracyjnej znajdował się w rękach nielicznej, elitarnej grupy, liderów stronnictw i niezależnych finansowo wyższych rangą dowódców wojskowych ${ }^{6}$. Napięcia i spory $w$ życiu politycznym nadwyrężały zaufanie

\footnotetext{
${ }^{5}$ ASN, Protokót z konferencji stronnictw..., s. 8.

${ }^{6}$ S. LUKASIEWICZ, Emigracyjny system polityczny, [w:] Polska emigracja polityczna 1939-1990. Stan badań, red. S. Łukasiewicz, Warszawa 2016, s. 42; T. WolszA, Polacy na emigracji 1945-1956, [w:] PRL od lipca 1944 do grudnia 70, red. K. Persak, P. Machcewicz, Warszawa 2010, s. 270.
} 
uchodźczej społeczności do emigracyjnej władzy; pod adresem rządu formułowano epitety typu: „lipa” (K. Tychota), „emigracyjna fantasmagoria z legalizmem w tle" (Z. Celichowski), „londyńska humoreska”. Co więcej, pojęciem „fikcyjny rząd” posługiwał się A. Ciołkosz, określenia „tzw. władzy” używali S. Mikołajczyk i T. Bielecki (Komunikat Prezydium SN nr 2, 1947, s. 7).

Faktycznie do istnienia rządu trzeba, żeby - przekonywał sympatyzujący ze SN S. Skrzypek, opiniotwórczy publicysta prasy polonijnej - rząd ten sprawował władzę. Może to być nieprzyjemne, ale według prawa międzynarodowego rządem polskim jest rząd Cyrankiewicza a nie żaden inny. Nasi ministrowie wnet będą tak śmieszni jak ministrowie ukraińscy czy gruzińscy. W świecie więcej znaczy reprezentatywne ciało, niż jacyś tam ministrowie i premierzy, których nawet sami Polacy przestali traktować serio?

Z nutą ironii o konstrukcji „państwa na uchodźstwie” wyrażali się liderzy ludowców z grupy Mikołajczyka i niektórzy socjaliści z grupy Zygmunta Zaremby („uwiędłym kształcie legalizmu” i „fikcji państwa i narodu na uchodźstwie") ${ }^{8}$.

W celu przywrócenia zaufania do rządu jako prawowitej władzy „państwa na uchodźstwie”, liderzy Rady Politycznej podjęli inicjatywę demokratyzacji życia politycznego. Na etapie negocjacji w sprawie utworzenia rządu po śmierci premiera Tadeusza Tomaszewskiego (1950) przedstawili prezydentowi za pośrednictwem prof. Henryka Paszkiewicza, wybitnego mediewisty, postulaty dotyczące demokratyzacji sposobu wykonywania art. 13 Konstytucji. Liczyli, że prezydent motywowany ideą ożywienia polityki polskiej powróci do wykonywania zobowiązań umowy paryskiej z 30 listopada 1939 r., tj. obejmie przyrzeczonymi wówczas konsultacjami z premierem w najważniejszych sprawach państwa przywódców stronnictw oraz zgodzi się na utworzenie parlamentu - Rady Jedności Narodowej. Postulaty ugrupowań antyprezydenckiej opozycji przedstawione w formule „londyńskiego paktu” były drugą, nie licząc zawieszonych prac Komisji Ustrojowej, od umowy paryskiej próbą demokratyzacji konstytucji poprzez uelastycznienie i uwspółcześnienie art. 13, określającego zakres prezydenckich prerogatyw ${ }^{9}$. Z powodu narastających napięć i nieufności między stronami negocjacji, liderami opozycji

\footnotetext{
${ }^{7}$ ASN, List S. Skrzypka do T. Bieleckiego z 24 VIII 1954.

${ }^{8}$ List Z. Zaremby do T. Bieleckiego z 12 VII 1956 w: Z. ZAREMBA, Listy 1946-1967, oprac. O. Blatonowa i A. Friszke, Warszawa 2000, s. 368.

${ }^{9}$ G. KULKA, Koncepcje prawno-ustrojowe Rady Narodowej RP na emigracji w latach 1939-1991, Warszawa 2009, s. 122.
} 
antyprezydenckiej a obozem „zamkowym”, wynik tych negocjacji był przesądzony. Wprawdzie obie strony zgodnie broniły stanowiska, że zmiana konstytucji leży w gestii kraju, lecz każda z nich za parawanem idei demokratyzacji chciała realizować partykularne interesy: prezydent bronił swojej konstytucyjnej pozycji, nie dostrzegał korzyści płynących ze „zmiękczenia” stanowiska w kwestii art. 13; z kolei celem ugrupowań antyprezydenckiej opozycji było zniesławienie Zaleskiego jako "szkodnika” polityki polskiej i przygotowanie $\mathrm{w}$ ten sposób gruntu do budowy nowego projektu politycznego - Zjednoczenia Narodowego, który umożliwiał liderom ugrupowań historycznych realizację własnych ambicji politycznych. Powołanie nowego, apolitycznego, „społecznego" rządu, oderwanego od stronnictw pod premierostwem gen. Romana Odzierzyńskiego, pogłębiło zamęt w emigracyjnym życiu politycznym, a podpisanie Aktu Zjednoczenia (14 marca 1954) ostatecznie przekreśliło nadzieję integracji i zniweczyło dotychczasowe wysiłki wzmocnienia atutu jednowładzy rządu emigracyjnego. Odtąd w Londynie funkcjonowały dwa rywalizujące ze sobą ośrodki życia politycznego, obydwa deklarowały przywiązanie do legalizmu: obóz prezydencki oskarżał liderów Zjednoczenia o uzależnienie polityki emigracyjnej od obcych źródeł finansowania i podporządkowanie jej „czynnikom obcym”, dyrektywom Departamentu Stanu za pośrednictwem Komitetu do Spraw Wolnej Europy (KWE ). Sprawa utrzymania niezależności dzieliła społeczność emigracyjną, przeważali obrońcy propagowanej przez Zaleskiego „polityki wartości”, „polityki honorowej” - działalności niezależnej finansowo. Zarzuty uzależnienia polityki polskiej od „obcych” - amerykańskich mocodawców rodziły wątpliwości wobec wiarygodności deklaracji liderów Rady Politycznej o wyborze walki politycznej z reżimem warszawskim z zamiarem przywrócenia „pełnej” suwerenności.

Wątpliwości te potęgowała sprawa Bergu, akcja o charakterze informacyjno-wywiadowczym zainicjowana przez liderów Rady Politycznej, uzgodniona z KWE, która doprowadziła do licznych aresztowań, represji i tortur. Liczba ofiar jest trudna do określenia (A. Adamczyk szacuje ją od 30 do 200, zarazem postuluje podjęcie dalszych badań). Sprawa ta wywołała falę krytyki pod adresem liderów Rady Politycznej, głównie ze SN (T. Bieleckiego, Edwarda Sojki, Zygmunta Berezowskiego). Ze strony ,jałtańczyków", adwersarzy politycznych T. Bieleckiego, pojawiały się zarzuty uzależnienia polityki polskiej od „czynników obcych”. W następstwie Bergu w monolitycznej strukturze Stronnictwa uwidoczniły się wyraźne pęknięcia, oznaki niezadowolenia i wyrazy krytyki pod adresem prezesa, te jednak dość 
szybko ustąpiły, nie zdołały nadwyrężyć jego pozycji ani nie wzmocniły siły jego adwersarza - J. Giertycha, ten wprawdzie zyskiwał popularność jako publicysta polityczny i propagator strategii negocjacji z rządem warszawskim, ale brakowało mu atutu doświadczenia organizacyjnego. Narodowcy nie oczekiwali na stanowisku prezesa publicysty lecz organizatora życia politycznego. Berg uaktualnił pytanie, jakie na początku lat pięćdziesiątych formułował Zaleski, dotyczące wysokości rachunku, jaki za udzielenie pomocy wystawią ugrupowaniom Rady Politycznej amerykańscy mocodawcy. „Afera Bergu - konstatuje S. Cenckiewicz - powinna być dziś przestrogą dla tych, którzy sądzą, że rezygnując z prowadzenia suwerennej polityki można w polityce cokolwiek osiągnąć [...]. Nie można być bowiem jednocześnie szpiegiem obcego państwa, nawet zaprzyjaźnionego i służyć Rzeczypospolitej”10.

Emigranci zajmowali niejednoznaczne stanowisko wobec kwestii finansowania polityki polskiej z „obcych” źródeł. Z jednej strony obawiali się ograniczenia niezależności - „ubezwłasnowolnienia”, z drugiej, ze zrozumieniem odnosili się do tej kwestii, ponieważ rządowi brakowało środków na pokrycie kosztów administracji, funkcjonowania placówek dyplomatycznych, organizacji polskiego szkolnictwa itp. Środki finansowe w dyspozycji rządu i ugrupowań politycznych określały zakres i charakter aktywności emigracyjnej oraz przydawały jej akcentów polityczności, tym bardziej że w początkowym etapie organizacji życia emigracyjnego narodowcy nie potrafili precyzyjnie określić kryteriów kwalifikacji działalności politycznej. Etatowi pracownicy placówek łączności z terenu Niemiec nie odczuwali stanu uczestnictwa w nadzwyczajnej misji o charakterze politycznym motywowanej idea odzyskania „pełnej suwerenności”, zarzuty, jakie czynili wobec organizatorów tej akcji, nie miały ideowego charakteru. Uważali, że ci narazili na represje niewinne osoby, a także utratę przez nich środków do życia, tym bardziej że wcześniej z namowy E. Sojki odrzucili oni ofertę wyjazdu do USA, ponieważ Sojka miał im gwarantować zatrudnienie ,aż do czasu powrotu do Kraju". Notabene emigranci, którzy wyjechali do USA, dość szybko wyzbyli się motywacji politycznej, inspiracji płynącej z „londyńskiego” źródła, nie rezygnując zarazem - co należy podkreślić - z działalności polonijnej $\mathrm{w}$ organizacjach społeczno-kulturalnych, polskim szkolnictwie, życiu sportowym itp. O niewielkiej skali aktywności politycznej, „uśpionych kołach SN w Nowym Jorku i Chicago" informował prezesa SN A. Niebieszczański w sprawozdaniach z lat pięćdziesiątych. Z powodu odmowy udziału

${ }^{10}$ S. CENCKIEWICZ, Oczami bezpieki. Szkice i materiały z dziejów aparatu bezpieczeństwa PRL, Kraków 2009, s. 28. 
pojawiły się trudności w organizacji oddziału TRJN w USA. Emigracji polskiej nie udało się uzyskać wsparcia moralnego opinii publicznej w USA, od lat sześćdziesiątych większe zainteresowanie budziła emigracja kubańska niż „londyńscy” emigracyjni „dyplomaci”. W opinii amerykańskiej „sprawa polska" w jej emigracyjnej wersji w ogóle nie istniała, redaktorzy amerykańskiej prasy nie opisywali życia społecznego w Polsce jako stanu „niewoli narodowej".

W marcu 1947 r. przedstawiciele SN podjęli rozmowy z oficerami amerykańskiego kontrwywiadu wojskowego na temat warunków współpracy i aspektów finansowych, o czym przekonuje treść raportu Franciszka Szwajdlera delegata MSW i Kazimierza Tychoty (członków SN) z rozmowy z mjr. Bretem [?] - szefem sekcji kontrwywiadu Counter Intelligence Corps:

P. Bret na wstępie rozmowy oświadczył - raportował Szwajdler - że jest mu wiadomym, iż minister Berezowski jest z National Democratic Party, że ja też jestem z tej partii i wie o tym, że praca MSW opiera się na tej właśnie partii. Wyraził zdziwienie, że dotychczas polskie czynniki londyńskie nie nawiązały kontaktu z nimi w sprawach tak ważnych dla obu stron, jak wspólna walka z komunizmem. Zapowiedział, że $\mathrm{w}$ tej chwili nie chce mówić o innych zagadnieniach, jak współpraca ofensywna na Polskę, lecz wie, że miarodajne czynniki amerykańskie zechcą na ten temat rozmawiać $\mathrm{z}$ nami ${ }^{11}$.

W podobnym celu, z zamiarem uzgodnienia warunków współdziałania emigracji z amerykańskim wywiadem, odbyło się spotkanie Kazimierza Odrobnego (SN) z Govenem [?] - przedstawicielem wywiadu brytyjskiego, który miał powiedzieć, że „zależy mu właśnie na oparciu tej współpracy na National Democratic Party”. „Jak wyczułem z wypowiedzi obu panów - relacjonował Odrobny - gwarancją polityczną dla nich jest fakt, że tę robotę robić będą ludzie z National Democratic Party" ${ }^{\prime 2}$. Trudno jednak określić, czy ustalone warunki zasady współdziałania zostały sfinalizowane dopiero w trakcie rozmów Edwarda Sojki (SN) w Departamencie Stanu (1947). O przebiegu tych spotkań z pewnością był informowany rząd i prezydent. Na tej podstawie A. Zaleski mógł zakładać, że aspekty finansowe amerykańskiej oferty współdziałania mogą skłonić liderów stronnictw antysanacyjnej opozycji do wyboru własnej drogi i rezygnacji z niezależnego kursu polityki polskiej. Liderzy stronnictw nie napotykali na przeszkody, które premierowi i prezy-

11 ASN, Sprawa amerykańska. Sprawozdanie adresowane do T. Bieleckiego, Frankfurt n/Menem, III, 1947, s. 2.

12 Tamże, s. 3. 
dentowi utrudniały nawiązanie kontaktów z Departamentem Stanu. Podejmowane na jesieni 1947 r. przez Józefa Lipskiego - byłego ambasadora RP w Berlinie - próby nawiązania kontaktów z Departamentem Stanu zakończyły się fiaskiem ${ }^{13}$. Z myślą o utrzymaniu legalizmu jako atutu władzy prezydenckiej, zagrożonego w sytuacji utworzenia Komitetu Narodowego, Zaleski wyłączył stronnictwa $\mathrm{z}$ udziału w rządzie premiera $\mathrm{T}$. Tomaszewskiego (1949-1950). Z pozycji obrońcy legalizmu Zaleski mógł liczyć na wsparcie liderów stronnictw historycznych - T. Bieleckiego i A. Ciołkosza, poparcia odmówił S. Mikołajczyk i nieokreślone bliżej środowiska ideowe, o których wspomina Bielecki w liście do Franciszka Szwajdlera (prezesa Komitetu Politycznego na terenie zachodnich stref okupacyjnych).

Postępujący naprzód atak na Rząd i jego strukturę opartą o stronnictwa, idący $\mathrm{z}$ dwu stron, a może gdzieś w kulisach kierowany jedną ręką. $1 . \mathrm{Z}$ jednej strony piłsudczycy starają się osłabić i podważyć zasadę partyjną, na której się Rząd opiera i poprzez reprezentacje społeczno-zawodowe, czyli przez Zjednoczenie starają się wytworzyć narzędzie do zmiany Rządu, bądź do przekształcenia jego struktury; 2. Z drugiej żywioły, związane z kołami międzynarodowymi, bliżej jeszcze niż piłsudczycy, lansują po cichu stworzenia czegoś w rodzaju Komitetu, co byłoby w gruncie rzeczy próbą zastąpienia Rządu i ułatwienia w ten sposób Anglosasom sytuacji w momencie, gdyby musieli o sprawie polskiej mówić, gdyż niewątpliwie nie jest dla nich rzeczą miłą traktowanie z legalnym rządem, którego nie uznali i wobec którego mają międzynarodowe zobowiązania, które złamali $^{14}$.

Sprawa utworzenia Komitetu Narodowego powróciła w 1949 r., jako propozycja KWE wraz $\mathrm{z}$ ofertą wsparcia finansowego, jednak nie zyskała akceptacji partii historycznych: PPS, SN i SP (wyłączając PSL Mikołajczyka). Jej przyjęciu sprzeciwiał się prezes $\mathrm{SN}-\mathrm{T}$. Bielecki, występujący wówczas w roli architekta polityki emigracyjnej. W jego opinii obrona legalizmu i ciągłości państwa była gwarantem utrzymania politycznego charakteru emigracji ${ }^{15}$. Sprzeciwiał się więc postulatom rezygnacji z legalizmu i zastąpienia rządu Komitetem Narodowym. „Amerykanie - przekonywał w rozmowie z Janem Wszelakim, przedstawicielem rządu w USA - wciąż wolą Komitet od rządu i gdyby doszło do zupełnego zerwania [z legalizmem

${ }^{13}$ K. TARKA, Emigracyjna dyplomacja. Polityka Rządu RP na Uchodźstwie 1945-1990, Warszawa 2003, s. 62 .

${ }^{14}$ ASN, List T. Bieleckiego do F. Szwajdlera z 27 II 1947.

${ }^{15}$ P. MACHCEWICZ, Emigracja w polityce międzynarodowej, Warszawa 1999, s. 12. 
- przyp. S.K.], pozycja rządu będzie nie do obronienia i za rok przestaną o nim mówić w Ameryce i co ważniejsze na emigracji"16. Walka o suwerenność Polski z pozycji Komitetu umniejszała znaczeniu biografii politycznej liderów stronnictw - polityków emigracyjnych; w heroicznym kształcie, jak się wydaje, mogli utrzymać ją tylko w ramach „państwa na uchodźstwie”. Co więcej, w akceptacji legalizmu T. Bielecki upatrywał szansy pozostania na scenie politycznej, obawiał się marginalizacji politycznej z powodu nierozliczonych „grzechów przeszłości”, zarzutów radykalnego nacjonalizmu i antysemityzmu formułowanych ze strony diaspory żydowskiej z USA ${ }^{17}$. Z myślą o uwiarygodnieniu przemiany ideowej zastąpił hasła programu politycznego SN deklaracją antykomunizmu - antykomunizm i antysowieckość stały się znakiem rozpoznawczym Stronnictwa. Pod sztandarem walki z komunizmem narodowcy zorganizowani na wzór „oddziału narodowego" wzięli udział w zimnowojennej rywalizacji, motywowani ideą „,pełnej” suwerenności.

Wyrazem przywrócenia „pełnej” suwerenności miało być odzyskanie Ziem Wschodnich i cofnięcie sowieckiej Rosji (ZSRR) do linii ryskiej z 1921 r., co emigranci określali jako przywrócenie „integralności terytorialnej Polski" ${ }^{18}$. Z czasem, od chwili rysującej się stabilizacji na linii WaszyngtonMoskwa, w społeczności emigracyjnej narastały jednak wątpliwości dotyczące postulatu odzyskania Lwowa i Wilna. O ile w pierwszych latach od zakończenia wojny motyw „cofnięcia Jałty” spełnił rolę czynnika mobilizacji politycznej emigracji (nie licząc postawy grupy „jałtańczyków”), stał się probierzem jej charakteru ideowego i wyrazem zbiorowej ideowej tożsamości, o tyle w latach następnych, w okresie stabilizacji między Wschodem i Zachodem pozostał zbędnym balastem, ograniczającym odwagę wyboru nowego, uwolnionego od gorsetu postawy „niezłomnej” stylu myślenia politycznego ${ }^{19}$.

W rzeczywistości - zauważał W. Borysiewicz - zagadnienie odłączonych ziem wschodnich jest fikcją i jako problem polityczny dla Polski zupełnie nie istnieje. Trudno wyobrazić sobie zaistnienie w przyszłości takiej sytuacji, aby Polska

\footnotetext{
${ }^{16}$ Instytut Polski i Muzeum im. Gen. Sikorskiego w Londynie [dalej: IPiMS], Kol. 39/11, Korespondencja J. Wszelakiego, rozmowa z T. Bieleckim w dniu 28 IV 1949. Notatki.

${ }^{17}$ M.J. Chodakiewicz, Żydzi i Polacy 1918-1955. Wspótistnienie - zagłada - komunizm, Warszawa 2005, s. 536.

${ }^{18}$ A. AdAmCZyK, Pitsudczycy w izolacji (1939-1954). Studium z dziejów struktur i myśli politycznej, Bełchatów 2008, s. 267n.

19 J. LenCZNAROWICZ, Jalta. W kręgu mitów założycielskich polskiej emigracji politycznej 1944-1956, Kraków 2009, s. 122-126; 320-330.
} 
miała możliwość przyłączenia utraconych ziem wschodnich, a już należy uważać za zupełnie wykluczone, aby Polska, gdy kiedyś odzyska wolność, zechciała te terytoria dla siebie rewindykować ${ }^{20}$.

Można by pominąć wypowiedź Borysiewicza, uznając ją za odosobnioną, pozbawioną siły opiniotwórczej, lecz w podobnym duchu odnosili się do tej kwestii szeregowi działacze emigracyjnych środowisk i grup politycznych, nie licząc ,jałtańczyków”, którzy traktowali „Jałtę” jako trwały fundament powojennego porządku europejskiego. Emigracyjne oczekiwania wyrażone w formule „cofnięcia Jałty” czy „renegocjacji Jałty”, nie znajdowały zrozumienia w kręgach politycznych państw zachodnich; dyplomaci z politowaniem odnosili się do emigracyjnych oczekiwań ,anulowania Jałty”.

W tym nurcie opinii sytuuje się wypowiedź gen. Dwighta Eisenhowera z rozmowy z gen. Kazimierzem Sosnkowskim (1952), w której określił on pakt jałtański jako „haniebny”, dodając, iż „powinien być niezwłocznie zniesiony" 21 . Obaj rozmówcy zdawali sobie sprawę, iż Stany Zjednoczone nie planują wypowiedzenia wojny w obronie państw Europy Środkowo-Wschodniej. Dyplomacji emigracyjnej nie udało się usytuować „sprawy polskiej” jako czynnika bezpieczeństwa europejskiego w katalogu celów amerykańskiej polityki zagranicznej. Co gorsza, emigracyjni dyplomaci goszczący w Departamencie Stanu nie potrafili bliżej określić sposobów „cofnięcia Jałty", a oczekiwania wybuchu kolejnej wojny w gruncie rzeczy służyły jedynie wzmocnieniu duchowemu emigracyjnej społeczności, o czym przekonuje wypowiedź prezesa SN z 1946 r.: „Nie wydaje mi się, aby przyszło szybko do starcia zbrojnego między Wschodem a Zachodem [...] na wojnę się nie zanosi”22, i z roku następnego: „nie przewiduję konfliktu popartego groźbą wojny w bliskiej przyszłości” ${ }^{23}$, i z lat późniejszych: „Nigdy nie łudziłem się, że będą nas wyzwalać zwłaszcza zbrojnie, więc nie mam do nich pretensji, wyzwolimy się sami" 24 .

$\mathrm{Na}$ bazie motywu wojny opierały strategię informacyjną i propagandową ugrupowania obozu prezydenckiego. Warunkiem „cofnięcia Jałty” miało być „pobicie Sowietów”. Plany powrotu do Lwowa nie uwzględniały aspiracji

${ }^{20}$ AAN, sygn. 138, Akta S. Łuckiego, List W. Borysiewicza do członków CWW SN, maj 1976, s. 2.

${ }^{21}$ ASN, Poufna notatka o rozmowach gen. Sosnkowskiego z gen. Eisenhowerem i gub. Stevensonem w ostatnim tygodniu amerykańskiej kampanii wyborczej, Nowy Jork, 30 X 1952, mps, s. 1.

${ }^{22}$ ASN, List T. Bieleckiego do W. Andersa z 16 I 1946.

${ }^{23}$ ASN, List T. Bieleckiego do A. Macielińskiego z 17 XII 1947.

${ }^{24}$ ASN, List T. Bieleckiego do L. Kopcia z 18 VIII 1960. 
terytorialnych Ukraińców, ci w hipotetycznym scenariuszu wydarzeń mieli zostać włączeni w granice niezależnej politycznie Polski na prawach mniejszości lub w ramach niezależnego państwa ukraińskiego, zbudowanego na gruzach sowieckiej Rosji (ZSRR). W tym nurcie myślenia sytuują się liczne koncepcje związków federacyjnych ${ }^{25}$, wśród nich interesująca wizja federacji Ukrainy-Litwy-Białorusi (ULB) i Polski Juliusza Mieroszewskiego, nakreślona na łamach paryskiej „Kultury”. Ukraińcy uzależniali jednak wejście do związku państw z Polską od jasnej deklaracji polskiej w sprawie pozostawienia Lwowa $w$ granicach niepodległej Ukrainy. Chcieli najpierw wzmocnić więzy tożsamości narodowej - „nacieszyć się niepodległością”.

Niezależnie od tego w środowiskach politycznych polskiej emigracji brakowało jednomyślności co do wyboru strategii rozbicia sowieckiej Rosji, jako warunku odzyskania pełnej suwerenności. Poglądy ekspertów emigracyjnych z KWE różniły się od opinii „realistów”, postulujących uelastycznienie stanowiska w obliczu zagrożenia rewizjonizmu niemieckiego i ukraińskiego antypolonizmu.

Polska pomimo jej zależności od Rosji - przekonywa S. Skrzypek - jest jednak państwem. Jest uznawana przez wszystkie państwa świata i traktowana przez nie - nie wyłączając Stanów Zjednoczonych - jakby była naprawdę niepodległa. Czy to się komuś podoba czy nie, gwarantem nienaruszalności naszych granic zachodnich jest Związek Sowiecki - i w tym aspekcie sojusz polsko-sowiecki nie jest wcale sprzeczny z polską racją stanu ${ }^{26}$.

W tym nurcie opinii sytuują się poglądy opiniotwórczego J. Giertycha i redakcji „Horyzontów”, który stał na stanowisku, iż w sytuacji pogłębiającej się izolacji rządu emigracyjnego na arenie międzynarodowej i wobec niepewnych, zwodniczych deklaracji amerykańskich w sprawie polskiej i z myślą o uaktywnieniu działalności, emigracja powinna dokonać rewizji antyreżimowego i antysowieckiego kursu i szukać nici porozumienia z rządem warszawskim. Warunkiem negocjacji - przekonywał - jest zejście z kursu polityki konfrontacyjnej względem sowieckiej Rosji (ZSRR). On sam zrobił pierwszy krok w tym kierunku, publikując na łamach „Horyzontów” (1956, $\mathrm{nr} 43$, s. 4) List otwarty do pana Nikity Chruszczowa, przewodniczacego Rady Ministrów ZSRR, w którym za cenę liberalizacji życia politycznego

${ }^{25} \mathrm{~J}$. ŁAPTOS, Europa marzycieli. Integracyjne wizje i projekty środkowoeuropejskiej emigracji politycznej (1940-1956), Kraków 2012, s. 244.

${ }^{26}$ S. SkrzYPeK, Ukraina i Polska, „Biuletyn Stronnictwa Narodowego w Stanach Zjednoczonych A.P." z marca 1980, nr 1, s. 6. 
w Polsce oferował zabezpieczenie granicy zachodniej przed atakiem niemieckim w sytuacji zagrożenia ze strony ChRL wschodnich rubieży Rosji (ZSRR). W liście tym ożywiał historyczną (wszechpolską) ideę „rozumnej ugody", opartą na motywie wzajemnych korzyści jako warunku współdziałania politycznego, ten jednak kłócił się ze stylem myślenia grupy „niezłomnej”, emigracyjnej donkiszoterii, która niezależnie od zmieniających się warunków otoczenia międzynarodowego broniła celów polityki polskiej, licząc na uwrażliwienie opinii międzynarodowej i zaangażowanie polityczne wynikające z motywów ideowych; obrony wolności i demokracji. Giertych nie ściągnął na siebie, jak można by tego oczekiwać, fali oburzenia, owszem, nie ustrzegł się krytyki i epitetów typu „renegat”, „zdrajca” itp. formułowanych zarówno ze strony opozycji, jak i z własnych szeregów, uczestników II Zjazdu Centralnego (Londyn, 19-22 maja 1961), którzy potwierdzili stanowisko CWW z Londynu o wydaleniu go z szeregów Stronnictwa, lecz liczba narodowców podzielających jego styl myślenia politycznego rosła, przybywało mu zwolenników tak wśród narodowców, jak i socjalistów, nie mówiąc szerzej o poparciu ,jałtańczyków”. Na ogół poparcie to nie miało otwartego charakteru, na łamach publicystyki „Myśli Polskiej” trudno byłoby znaleźć głosy sympatii, te zostały wyrażone w treści korespondencji adresowanej do „londyńskiej” centrali SN. List Giertycha, jak i następny z 1976 r., adresowany do społeczeństwa w kraju, można było zignorować, uznając go za kolejny występek publicysty, który od lat chodzi własnymi ścieżkami myśli politycznej. Stało się jednak inaczej, liderzy SN i PPS bronili własnych biografii politycznych i utrwalonego stylu myślenia, który Giertych wystawił na próbę. W tym kontekście jego publicystyka polityczna była w mojej opinii pierwszą próbą uwspółcześnienia - adaptacji do zmienionych warunków otoczenia międzynarodowego historycznego kształtu myśli narodowej (narodowcy nie posługiwali się pojęciem „myśl nacjonalistyczna” ${ }^{27}$ ) i burzyła utrwalone schematy myślenia.

Niewielu spośród narodowców poszło jego śladem. Do grupy „niezależnych” zaliczyłbym Witolda Leitgebera, który na forum KP SN w dniu 29 stycznia 1986 r. w referacie pt. „Ideologia narodowa w świetle krytyki w kraju” sformułował trzy pytania: „Czy ideologii narodowej, która formowała się w tak odmiennych od naszych czasów, nie należałoby poddać weryfikacji by nie używać słowa rewizjonizm; Czy pewne sprawy nie zdezaktualizowały się; Czy nie należałoby zastanowić się nad tym, co trwałe i dobre, a co można

${ }^{27}$ ASN, M.E. RoJEK, Podstawy ideowe oraz niektóre zagadnienia ideowe Stronnictwa Narodowego, Londyn 1950. 
by odrzucić?". Członkowie tego gremium zajęci obserwacją wydarzeń krajowych pozostawili te pytania bez odpowiedzi. Także w tym okresie, w dobie rewolucji „solidarnościowej” ujawnił się autonomiczny charakter poglądów Giertycha dotyczących oceny decyzji gen. Jaruzelskiego o wprowadzeniu stanu wojennego i profilu ideowego ruchu „Solidarność”. W ocenie obu tych kwestii narodowcom nie udało się osiągnąć jednomyślności. W szerokiej akcji potępienia tej decyzji znalazły się głosy zrozumienia, wyrażone w formule „mniejszego zła” i ,adekwatnej reakcji”. W tym nurcie sytuuje się opinia A. Skrzypka: „Gdyby [Jaruzelski - przyp. S.K.] - przekonywał - nie zrobił tego, co zrobił, ofiary byłyby wielkie [...]. Liczymy się z rzeczywistością i nie popieramy ekstremizmu. Ważniejszą od walki z komunizmem jest sprawa istnienia Polski jako państwa i zachowanie szansy uratowania podstawowych swobód obywatelskich" ${ }^{28}$. Echo tej opinii można znaleźć w ocenie historii współczesnych ugrupowań postendecji. Co więcej, od 1956 r. w myśli politycznej publicysty „Horyzontów” pojawia się motyw „samowyzwolenia", czyli samorzutnie postępującej liberalizacji życia społecznego i politycznego pod wpływem nowych prądów ideowych i czynników rozwoju cywilizacyjnego (technologii produkcji, wymiany handlowej, rozwoju medycyny itp.), w czym upatrywał nadziei odzyskania niezależności politycznej.

Z ideą odzyskania pełnej suwerenności wiąże się zagadnienie odbudowy narodowego charakteru życia społecznego w ramach nowego ustroju politycznego zniekształconego pod wpływem sowietyzacji. W opinii narodowców sowietyzacja przyczyniła się do osłabienia więzów tożsamości zbiorowej: tradycji, religii katolickiej i patriotyzmu. Stąd pierwszym zadaniem emigracji po powrocie do Kraju miało być przywrócenie wychowawczej roli edukacji historycznej i patriotycznej. Z pozycji „ocenzurowanej” planowali ściągnąć dwa kluczowe zagadnienia: historia relacji polsko-rosyjskich i polsko-żydowskich, w czym upatrywano szansy oczyszczenia Polaków z nieuzasadnionych $\mathrm{w}$ opinii narodowców zarzutów wrogości zarówno wobec wschodniego sąsiada, jak i polskich Żydów. Na pytanie, czy emigranci podjęli działania w tym kierunku, trzeba odpowiedzieć przecząco, co może wydawać się dość dziwne, gdyż na emigracji przebywało wielu wybitnych historyków, ci jednak nie podejmowali eksploracji historii najnowszej ${ }^{29}$. Nie deprecjonując roli emigracyjnych historyków w badaniach naukowych, wielu z nich zapisało się mocnymi zgłoskami w historiografii polskiej, to jednak

${ }^{28}$ ASN, S. SKRZYPEK, Uwagi na tematy krajowe, mps, b. m. 1982 [?].

${ }^{29}$ R. STOBIECKI, Klio na wygnaniu. Z dziejów polskiej historiografii na uchodźstwie $w$ Wielkiej Brytanii po 1945 r., Poznań 2005, s. 271. 
nie wystąpili z inicjatywą opracowania programów i podręczników kształcenia historycznego przeznaczonych dla polskiej szkoły $\mathrm{w}$ warunkach suwerennego państwa, z zamiarem wyjaśnienia zawiłych relacji z sąsiadami i stosunków polsko-żydowskich $\mathrm{w}$ ramach mieszanej komisji historycznej złożonej z przedstawicieli emigracyjnych instytutów naukowych i diaspory polskich Żydów w USA. Ustalenia tej komisji byłyby, jak się wydaje, dobrym punktem wyjścia w konstruowaniu programów współczesnej edukacji historycznej. Z bliżej nieznanych mi powodów nie udało się włączyć emigracji do inicjatywy przygotowania podręcznika na temat Holocaustu, o czym wspomina Jerzy Ptakowski - więzień Auschwitz - uczestniczący w międzynarodowej konferencji „Holocaust and Genocide”, zorganizowanej przez Departament Edukacji (Albany, 11-14 listopada 1982) ${ }^{30}$. W idei powołania wspólnych zespołów historyków można by upatrywać pierwszego kroku na drodze wyjaśnienia trudnego sąsiedztwa z Ukrainą i Litwą. Z różnych względów, przede wszystkim ograniczeń finansowych, które utrudniały dostęp do opiniotwórczych mediów państw zachodnich, nie udało się zorganizować kampanii informacyjnej w obronie dobrego imienia Polski, jako państwa o tradycji demokratycznej. Myśl o pozyskaniu przychylności opinii publicznej Zachodu dla postulatów emigracyjnych w dużym stopniu (?) osłabiała nieznajomość historii Polski. Z braku anglojęzycznej wersji opracowań wyniki badań naukowych prowadzonych w polskich instytutach i placówkach badawczych nie opuściły kręgu emigracyjnego odbiorcy - czytelnika i jako bibliofilskie eksponaty znalazły się na półkach domowych bibliotek (kwerenda archiwaliów nie dostarczyła informacji, że opracowania mogły być wykorzystane w pracy ekspertów z polskiej grupy w KWE).

Niezależnie od wątpliwości dotyczących poziomu przygotowania narodowców, wychowawców i pedagogów do reformy systemu wychowania, kształcenia historyczno-patriotycznego jako warunku moralnego odrodzenia narodu i warunku sine qua non odbudowania ustroju narodowego, znaki zapytania rodzi kwestia ustroju politycznego, na jakich zasadach prawnokonstytucyjnych miał być oparty ustrój polityczny okresu przejściowego, do czasu organizacji wolnych wyborów. Na podstawie szczątkowych informacji zaczerpniętych z prasy i komunikatów CWW SN z początku dekady lat pięćdziesiątych trudno jednoznacznie stwierdzić, czy w okresie przejściowym miały obowiązywać zasady Konstytucji kwietniowej w jej zmodyfikowanej formie, explicite wyrażone $\mathrm{w}$ postulatach tzw. paktu londyńskiego (16-29

30 J. PTAKOwSKI w: „Biuletyn Stronnictwa Narodowego w Stanach Zjednoczonych A.P.” wrzesień 1982-marzec 1983, s. 11. 
września 1950), na którym od 1954 r. opierała się konstrukcja obozu Zjednoczenia. Z pewnością można powiedzieć, że wykluczano możliwość przywrócenia Konstytucji kwietniowej w jej pierwotnej, „czystej” postaci. Wydaje się, że do czasu wyborów miałyby obowiązywać zasady ustrojowe Konstytucji kwietniowej w jej „zdemokratyzowanej” postaci, wyrażonej w uelastycznieniu art. 13 (nie uwzględniano możliwości przywrócenia Konstytucji marcowej, ta bowiem pozbawiała stronnictwa atutu legalizmu). Stwierdzenie to narażone jest jednak na zarzut błędnej interpretacji, gdyż informacje $z$ tego okresu są obciążone balastem rywalizacji politycznej $z$ sanacją $\mathrm{i}$ walki propagandowej z reżimem warszawskim. Myśl polityczna emigracyjnej endecji w tym okresie jak i w latach następnych nie miała autentycznego, lecz refleksyjny charakter, była formą reakcji na ataki propagandy reżimowej i zaczepki oponentów politycznych w środowisku ,polskiego” Londynu. A ponieważ narodowcy nie opracowali zwartego studium z zakresu filozofii politycznej na wzór Państwa narodowego Stanisława Grabskiego, to niemożliwe wydaje się rozpoznanie w refleksji politycznej emigracyjnej endecji wątków motywowanych wyzwaniami walki ideowej i politycznej.

$\mathrm{Na}$ fundamentach Konstytucji kwietniowej w jej zdemokratyzowanej wersji miał być oparty ustrój polityczny, wyrażony w formie „demokracji narodowej”. Publicyści „Myśli Polskiej” nie określili bliżej charakteru ideowego tej formy. Narodowcy pod wpływem obserwacji życia społecznego Zachodu odwrócili się od ustroju państwa narodowego w jego przedwojennej postaci, nasyconej pierwiastkami ekskluzywnego nacjonalizmu ${ }^{31}$. W aspekcie ustrojowym idea odzyskania pełnej suwerenności nie wyrażała się więc w dążeniu do przywrócenia form ustrojowych sprzed lat. „Epoka Dmowskiego” się skończyła, nie ma sensu powracać do tamtych lat, idą nowe idee - zauważał S. Kozanecki - trzeba się, parafrazując jego myśli, do nich przystosować ${ }^{32}$.

Z końcem epoki Dmowskiego utraciły znaczenie historyczne motywy kształtujące „narodowy” charakter celów edukacji społecznej wyrażone w tzw. kwestii żydowskiej. Nie oznacza to jednak - przekonują liderzy SN zakończenia rywalizacji polsko-żydowskiej, ta zmieniła jedynie swój charakter. W jubileuszowym wydaniu „Gazety Warszawskiej” (Londyn, 31 XII 1974) Bielecki, odnosząc się do tej kwestii, pisał:

\footnotetext{
${ }^{31}$ AAN, sygn. 182, Akta S. Łuckiego, List S. Łuckiego do (autor nieustalony) W. Wasiutyńskiego [?] z 28 VII 1961.

32 AAN, sygn. 177, Akta S. Łuckiego, Idzie nowe (refleksje w związu z VII Światowym Zjazdem SN w Londynie), Bruksela, 1 X 1992.
} 
Dziś kwestia żydowska ma po wojennych, okrutnych prześladowaniach zupełnie inny charakter i wymiar. I Żydzi i my byliśmy bezlitośnie tępieni przez Hitlera, co wytworzyło solidarność wobec wspólnego wroga. W każdym razie obóz narodowy rozwiązywał kwestię żydowską przed ostatnią wojną własnymi metodami, przez popieranie polskiego handlu i rzemiosła, a nie przez wysiedlanie siłą bądź fizyczne tępienie, co go wyraźnie odcinało zarówno od hitlerowskich jak i od sowieckich sposobów traktowania Żydów.

Co więcej, rywalizacja polsko-żydowska o ustalenie tytułu „gospodarza” jest trwałym elementem życia politycznego i nigdy się nie skończy, co gorsza, jest wykorzystywana $\mathrm{w}$ imperialnej polityce sowieckiej, jej wyrazem miała być „żydokomuna”. Ograniczenie udziału Żydów w życiu politycznym było postrzegane jako ważny motyw idei odzyskania „pełnej” suwerenności, stąd też narodowcy-publicyści „Myśli Polskiej” powstrzymywali się od jednoznacznie optymistycznie brzmiącej oceny wydarzeń w dobie „Solidarności”, w kręgu doradców odnajdywali bowiem byłych działaczy pochodzenia żydowskiego o komunistycznym rodowodzie. Wyrazem ,żydowskiego wpływu” miało być wprowadzenie do procesu zmian ,atmosfery walki”, odrzucenie idei stopniowego reformowania ustroju na rzecz wyboru strategii konfrontacyjnej. „Ale zachowujmy - apelował T. Rzewuski do członków Komitetu Organizacyjnego Centralnego Zjazdu SN - naszą nieufność i czujność wobec sił, które pod maską różnych pięknych haseł, postępu, sprawiedliwości, bohaterstwa, a jak wygodniej, to i patriotyzmu służą ambicjom obcym i często wrogim naszemu narodowi”33. W tym nurcie opinii sytuują się głosy A. Dargasa, nie mówiąc szerzej o poglądach J. Giertycha i S. Kozaneckiego. Na tym tle wyjątkowe miejsce zajmuje apel Witolda Nowosada (z podobnym wcześniej wystąpił W. Leitgeber) o pojednanie z Żydami - jak można przypuszczać, w ramach nowego programu edukacji historycznej i obywatelskiej - w celu przywrócenia dobrego imienia w opinii międzynarodowej. „Ogromną rolę odgrywa sprawa żydowska i nasze Stronnictwo powinno poddać rewizji cały swój stosunek do tej kwestii w duchu humanizmu chrześcijańskiego" ${ }^{34}$. Apel ten pozostał bez echa, co nie może dziwić, publicystyka „Myśli Polskiej” utraciła rolę czynnika opinii, a ideowo-polityczny charakter grupy narodowców, publicystów tego pisma, kształtował li tylko motyw walki z sanacją i antysanacyjne resentymenty. Stronnictwo traciło swoją historyczną tożsamość i poddawało się procesom polonizacji. $Z$ tego powodu,

\footnotetext{
${ }^{33}$ AAN, sygn. 182, Akta S. Łuckiego, List T. Rzewuskiego z 20 V 1982, rkps, s. 2.

${ }^{34}$ AAN, sygn. 123, Akta S. Łuckiego, List W. Nowosada do A. Dargasa z 10 VI 1991.
} 
chcąc utrzymać ideowy profil Stronnictwa, jego liderzy nie przyjęli oferty Alojzego Mazewskiego - prezesa Kongresu Polonii Amerykańskiej - ujednolicenia celów i form działalności.

Pierwsze symptomy słabnięcia ideowego charakteru narodowców, jako grupy politycznej walczącej o odzyskanie „pełnej” suwerenności, pojawiły się zanim prezes KPA wystąpił z inicjatywą wspólnego działania pod szyldem Polonii na początku dekady lat pięćdziesiątych z chwilą dezintegracji „polskiego" Londynu. Już wówczas narodowcy wycofywali się z życia politycznego. Nie odmawiali pomocy materialnej, udzielali się w życiu organizacji społecznych i kulturalnych, lecz liczba prenumeratorów „Myśli Polskiej”, uczestników zjazdów centralnych malała. Spośród kilku przyczyn politycznej alienacji narodowców decydujące znaczenie miały dwa czynniki. Pierwszy związany był z uruchomieniem KWE w roli wiodącego ośrodka polityki polskiej, który przejął od emigracji (narodowców) zadanie utrzymania łączności z krajem z zamiarem ożywienia „sił własnych narodu” jako zalążka opozycji antysystemowej, co nie udało się narodowcom (afera Bergu), ci jednak odtąd mieli występować w roli podwykonawców amerykańskiej strategii wyzwolenia.

Londynu sensu stricte w ich pojęciu [zarządu KWE - przyp. S.K.] w ogóle nie ma - pisał Jan Wszelaki - jest to coś w rodzaju legitymistów austriackich lub monarchistów rosyjskich [...]. W ten sposób na polskim odcinku, i tylko tym jednym, powstaje coś w rodzaju komisarycznego zarządu nad masą upadłościową, czy nad niepełnosprawnym, czy wreszcie nad wariatem. To nie jest metafora, bo tak ludzie myślą i mówią tutaj. Tylko nieaktualność sprawy polskiej i w ogóle wschodnioeuropejskiej odsuwa na razie tezę o niezdolności Polaków do zajmowania się ich własnymi interesami ${ }^{35}$.

Drugi czynnik związany był $\mathrm{z}$ rozbudzeniem nastrojów niezadowolenia młodego pokolenia wobec warunków życia społecznego i kontestacji władzy. W wydarzeniach w kraju - „przełomowych” $(1956,1968,1980)$ nie widać inspiracji narodowców. Wśród inicjatorów, ekspertów i doradców nie ma nazwiska prezesa SN, członków CWW ani przewodniczącego quasi-emigracyjnego parlamentu Tymczasowego Rządu Jedności Narodowej (RJN), pojawiają się natomiast nowi bohaterowie, liderzy związkowi, którzy podejmowali walkę z reżimem według własnych wyobrażeń życia politycznego, nie oczekiwali emigracyjnej podpowiedzi, nazwiska emigracyjnych polity-

${ }^{35}$ IPiMS, kol. 39/11, Korespondencja Jana Wszelakiego, List J Wszelakiego do M. Arciszewskiego (Buenos Aires) z 12 VI 1950. W tym samym duchu list J. Wszelakiego do H. Stebelskiego z 20 IV 1953 (m.in. o nieufności KWE wobec polskiej emigracji). 
ków, dyplomatów, premierów i prezydentów nie rodziły skojarzeń. W sytuacji słabnącej roli liderów emigracyjnych stronnictw w następstwie przekazania steru polityki polskiej do KWE, rosło znaczenie ośrodków myśli politycznej, przede wszystkim paryskiej „Kultury”. W redakcji tego pisma - tak odczytuję wyniki badań Rafała Habielskiego - zagadnienia obciążone balastem historii, ograniczone gorsetem resentymentów historycznych (sąsiedztwa wschodniego i relacji z Niemcami itd.) nabrały nowego znaczenia i w odideologizowanej wersji stały się intelektualną formą udziału emigracji w przemianach politycznych w kraju. Redakcja - jak ujął to cytowany autor - oparła się wpływom niezłomności - myśleniu w kategoriach „polityki wartości”36.

Od lat pięćdziesiątych na drodze polityki polskiej - walki o odzyskanie pełnej suwerenności, stanęła sprawa integracji europejskiej. Emigracyjni narodowcy z uwagą śledzili początki procesu jednoczenia Europy, uczestniczyli w klubach dyskusyjnych, gościli na kongresie haskim (1948) i jako uczestnicy konferencji Ruchu Europejskiego (Londyn, 21-24 stycznia 1952) poświęconej zagadnieniom Europy Środkowo-Wschodniej (T. Bielecki, Z. Berezowski, A. Dargas, W. Folkierski, E. Sojka, Z. Stypułkowski) analizowali etapy procesu integracji politycznej i militarnej, szukając implikacji dla sprawy polskiej. Nie opracowali jednak dojrzałego studium na temat politycznych i gospodarczych aspektów tego procesu. Co więcej, w publicystyce politycznej „Myśli Polskiej” zagadnienie integracji zajmowało drugoplanowe miejsce; informacje o jednoczeniu Europy nie pasowały do emigracyjnej narracji o rosnącym napięciu na linii Wschód-Zachód i zapowiedzi nieuchronnego konfliktu światowego. W centrum dyskusji znalazła się sprawa form integracji i przyszłości państwa narodowego, ignorowano znaczenie aspektów gospodarczych i budowy systemu bezpieczeństwa zbiorowego. „Trzeba wyraźnie zaznaczyć - zauważa badacz tej problematyki - że dla publicystów narodowych ważny był spór o formę zjednoczenia, natomiast z lekceważeniem odnosili się oni do innego sporu, dotyczącego modelu gospodarczego zjednoczonej Europy" ${ }^{37}$. Spór o formę zjednoczenia nie został rozstrzygnięty, nie to było jego celem, liczył się sam fakt rozbudzenia dyskusji jako świadectwa aktywności politycznej. W nurcie opinii na ten temat uwidoczniły się dwa punkty widzenia, dwie formy integracji: federacji - opartej na idei unifikacji prawno-politycznej państwa w kierunku stworzenia superpaństwa ze wspólnym rządem, oraz konfederacji - „Europy ojczyzn” - „Europy suwerennych

\footnotetext{
${ }^{36}$ R. HABIELSKI, Życie społeczne i kulturalne emigracji, Warszawa 1999, s. 247.

${ }^{37}$ W. Turek, Od Jalty do zjednoczonej Europy. Polityka emigracyjnego Stronnictwa Narodowego w latach 1958-1968, „Arcana” 2003, nr 51-52, s. 222.
} 
państw". Narodowcy opowiadali się za wyborem drugiej formy, co wynikało ze sceptycznego nastawienia wobec idei federacji, niewiary w to, że państwa mogą wyzbyć się suwerenności lub co najmniej przekazać jej część na rzecz „wspólnoty” w zamian za uzyskanie gwarancji bezpieczeństwa. „Nawet gdyby ktoś chciał przyjąć - przekonywał prezes SN - że federacja w sensie ściślejszym jest najlepszą formą połączeń międzypaństwowych - trudno marzyć o wprowadzeniu jej w życie. Jest to muzyka dalekiej przyszłości i nie wiadomo, czy w najbardziej nawet sprzyjających warunkach da się stworzyć Stany Zjednoczone Europy" 38 .

W opinii narodowców integracja jest procesem organicznym, nie można jej aranżować. Projekt superpaństwa był postrzegany jako nienaturalny, zaprogramowany, wyjałowiony z wartości chrześcijańskich - „wytwór masońskiej inżynierii", podporządkowanej planom wprowadzenia nowego porządku światowego ${ }^{39}$. Z tego względu odmawiali poparcia idei ścisłej federacji, superpaństwa. Nie wykluczali uczestnictwa w bliżej nieokreślonej unii polityczno-gospodarczej państw słowiańskich - „Wspólnocie Słowian” lub związku państw Europy Środkowo-Wschodniej, opartym na idei piastowskiej pod warunkiem odbudowania pełnej suwerenności i narodowego charakteru życia politycznego. „Zadaniem pierwszym - przypominał prezes SN - jest uwolnienie naszych krajów z niewoli. Dopiero wolne, zdolne do decydowania o swoich losach narody można będzie związać w większe zgrupowanie. Stad też mniej bym dziś zajmował się pisaniem konstytucji przyszłego związku, a więcej łączeniem realnych sił do walki o wyzwolenie" ${ }^{40}$. Informacje o jednoczeniu Europy, wyzbyciu się części suwerenności na rzecz idei wspólnego europejskiego domu - „europejskiej rodziny państw” osłabiały emigracyjną wolę walki o odzyskanie suwerenności. Co więcej, warunkiem poparcia koncepcji wspólnej Europy z udziałem RFN, jako jej siły napędowej, było wyzbycie się antyniemieckiej fobii i usunięcie Niemiec z narracji politycznej jako wroga i motywu zagrożenia granicy zachodniej, co nie było łatwe, burzyło bowiem tradycyjne schematy myślenia politycznego.

\footnotetext{
${ }^{38}$ T. BieleCKI, Wegiel, stal i wojsko. Prez. T. Bielecki o próbach zjednoczenia Europy Zachodniej, „Myśl Polska” 1 III 1953, s. 7.

${ }^{39}$ [b. a.], Chrześcijańska wspólnota Europy, „Biuletyn Stronnictwa Narodowego w USA” kwiecień-sierpień 1981, nr 2, s. 3.

${ }^{40}$ Europa nie może zostać podzielona. Przemówienie prezesa Tadeusza Bieleckiego, „Myśl Polska" 1-15 III 1952, nr 193, s. 2.
} 
W uchwale ostatniego VII Centralnego Zjazdu Stronnictwa Narodowego (Londyn, 4-6 września 1992), zamykającego ostatni etap działalności emigracyjnego SN, zapisano: „Wobec odzyskania przez Polskę niepodległości i odrodzenia życia politycznego w Kraju, zamknąć dotychczasową działalność Stronnictwa Narodowego na Przymusowym Uchodźstwie" ${ }^{41}$. W ten sposób narodowcy potwierdzili, iż zwierzchnictwo narodu w kształtowaniu dla siebie form życia politycznego zostało przywrócone, że sytuacja polityczna w kraju spełnia kryteria „pełnej” suwerenności. Liderzy krajowych ugrupowań politycznych nawiązujących do tradycji ruchu narodowego nie otrzymali jednak od emigracyjnych kolegów, uczestników kongresu założycielskiego Stronnictwa Narodowo-Demokratycznego (Warszawa, 22-23 czerwca 1991) ${ }^{42}$, wskazówek i podpowiedzi w budowie nowoczesnego programu politycznego adresowanego do szerszego odbiorcy - pokolenia suwerennej Polski. W poszukiwaniu własnej drogi ideowo-politycznej zwrócili się w stronę myśli antenatów ruchu narodowego, ignorując znaczenie czynników postępu cywilizacyjnego (dyfuzji idei społecznych, automatyzacji produkcji i zagrożenia problemów globalnych). Co więcej, emigranci nie przekazali „instrukcji” opinii i koncepcji - dotyczących utrzymania i obrony odzyskanej suwerenności w jej ,pełnej” postaci.

BIBLIOGRAFIA

\section{Źródła}

Archiwum Akt Nowych [AAN]

Akta Stanisława Łuckiego

Archiwum Stronnictwa Narodowego [ASN]

Zbiory Tadeusza Bieleckiego i Zygmunta Berezowskiego

Instytut Polski i Muzeum im. Gen. Sikorskiego w Londynie [IPiMS]

Zbiory Jana Wszelakiego

Protokoły z obrad TRJN

Akta Stanisława Sopickiego

Biblioteka Uniwersytetu Mikołaja Kopernika w Toruniu

„Archiwum Emigracji”, papiery Zygmunta Celichowskiego

${ }^{41}$ J. BARANIECKI, Zarys działalności Stronnictwa Narodowego w latach 1939-1995 poza granicami Polski, Londyn 1995 (Aneks 2/1).

${ }^{42}$ AAN, sygn. 123, Akta S. Łuckiego, List S. Łuckiego do W. Nettera z 7 IX 1991. 


\section{Prasa}

„Biuletyn Stronnictwa Narodowego w Stanach Zjednoczonych A.P.” 1980, 1981, 1982-1983

„Myśl Polska” 1950, 1952, 1953

\section{Literatura}

ADAMCZYK A., Piłsudczycy w izolacji (1939-1954). Studium z dziejów struktur i myśli politycznej, Bełchatów: Instytut Józefa Piłsudskiego w Warszawie 2008.

BARANIECKI P.J., Zarys działalności Stronnictwa Narodowego w latach 1939-1995 poza granicami Polski, Londyn 1995 (Aneks 2/1).

CENCKIEwICz S., Oczami bezpieki. Szkice i materiały z dziejów aparatu bezpieczeństwa PRL, Kraków: Wydawnictwo Arcana 2009.

ChodAkiewicz J.M., Żydzi i Polacy 1918-1955. Współistnienie - zagłada - komunizm, Warszawa: Wydawnictwo Capital 2005.

Czaputowicz J., Suwerenność, Warszawa: Polski Instytut Spraw Międzynarodowych 2018.

FrISZKE A., Życie polityczne emigracji, Warszawa: Biblioteka WIĘZI 1999.

HABIELSKI R., Życie społeczne i kulturalne emigracji, Warszawa: Biblioteka WIĘZI 1999.

KILIAN S., Myśl społeczno-polityczna Tadeusza Bieleckiego, Kraków: Wydawnictwo Naukowe Akademii Pedagogicznej w Krakowie 2000.

KulKa G., Koncepcje prawno-ustrojowe Rady Narodowej RP na emigracji w latach 1939-1991, Warszawa: Wydawnictwo Sejmowe 2009.

LENCZNAROWICZ J., Jałta. W kręgu mitów założycielskich polskiej emigracji politycznej 1944 -1956, Kraków: Księgarnia Akademicka 2009.

ŁAPTOS J., Europa marzycieli. Integracyjne wizje i projekty środkowoeuropejskiej emigracji politycznej (1940-1956), Kraków: Wydawnictwo Naukowe Uniwersytetu Pedagogicznego 2012.

ŁUKASIEwICZ S., Emigracyjny system polityczny, [w:] Polska emigracja polityczna 1939-1990. Stan badań, red. S. Łukasiewicz, Warszawa: Instytut Pamięci Narodowej 2016.

MACHCEWICZ P., Emigracja w polityce międzynarodowej, Warszawa: Biblioteka WIĘZI 1999.

TARKA K., Emigracyjna dyplomacja. Polityka Rządu RP na Uchodźstwie 1945-1990, Warszawa: Oficyna Wydawnicza RYTM 2003.

SIKORSKI T., Wyznajemy zasady narodowe polskie i uniwersalne katolickie. Stronnictwo Narodowe na emigracji (1939-1992). Zarys działalności i myśli politycznej, Angielski łącznik. Albin Tybulewicz (1929-2014), Warszawa: Muzeum Historii Polski 2016.

Stobiecki R., Klio na wygnaniu. Z dziejów polskiej historiografii na uchodźstwie w Wielkiej Brytanii po 1945 r., Poznań: Wydawnictwo Poznańskie 2005.

TureK W., Od Jałty do zjednoczonej Europy. Polityka emigracyjnego Stronnictwa Narodowego w latach 1958-1968, „Arcana” 2003, nr 51-52, s. 217-227.

Wolsza T., Polacy na emigracji 1945-1956, [w:] PRL od lipca 44 do grudnia 70, red. K. Persak, P. Machcewicz, Warszawa: Bellona 2010.

ZAREMBA Z., Listy 1946-1967, oprac. O. Blatonowa, A. Friszke, Warszawa: ISP PAN 2000. 


\section{MOTYW „PEŁNEJ” SUWERENNOŚCI W MYŚLI POLITYCZNEJ EMIGRACYJNEGO STRONNICTWA NARODOWEGO W LATACH 1945-1989}

\section{Streszczenie}

Od pierwszych lat powojennych działalność polityczna emigracji była podporządkowana idei odzyskania pełnej suwerenności. Emigracyjni politycy stali na stanowisku, iż w następstwie układu jałtańskiego Polska utraciła suwerenność, stała się państwem zależnym w sowieckiej strefie wpływów, a polityka rządu warszawskiego, „marionetkowego”, doprowadziła do pogłębienia stanu zależności od ZSRR. W tym kontekście głównym zadaniem polityki emigracyjnej było „cofnięcie Jałty" i przywrócenie suwerenności oraz wzmocnienie więzów tożsamości narodowej. Celem badawczym artykułu jest wyjaśnienie pojęcia „pełnej suwerenności” - ukazanie jej brakujących elementów jako motywu polityki polskiej emigracji. W sferze zainteresowań badawczych sytuuje się analiza czynników kształtujących charakter emigracyjnej batalii o odzyskanie niezależności politycznej: zimnowojennej rywalizacji między Wschodem i Zachodem oraz integracji europejskiej. Charakter wykorzystanych źródeł, głównie materiałów z życia emigracyjnego Stronnictwa Narodowego kwalifikuje treść celu badawczego do obszaru myśli politycznej ugrupowań obozu legalistycznego. Liderzy tych ugrupowań jednym głosem mówili o strategii odzyskania pełnej suwerenności. Wyniki badań upoważniają do stwierdzenia, iż motyw „pełnej suwerenności" stał się fundamentem akcji informacyjnej, organizowanej od pierwszych lat powojennych z zamiarem mobilizacji politycznej emigracyjnej społeczności do aktywności politycznej.

Słowa kluczowe: emigracja polityczna; polityka polska; suwerenność; integracja europejska

\section{THE MOTIVE OF "FULL” SOVEREIGNTY IN THE POLITICAL THOUGHT OF THE NATIONAL PARTY IN EMIGRATION IN THE YEARS 1945-1989}

\section{Summary}

From the early post-war years on, the political activity of Polish émigrés was driven by the desire to see Poland regaining its full sovereignty. Polish politicians in exile were of the opinion that, as a result of the 1945 Yalta Conference, Poland lost its sovereignty and became a Sovietdependent state. Moreover, the political agenda of the Warsaw-based "puppet" government led to the deepening of the state of dependence on the USSR. Given the foregoing, the main political objective was to "undo Yalta," restore sovereignty, and strengthen the bonds of national identity. The research aim of the article is to explain the concept of "full sovereignty" and to expose its missing elements as a driver of the political strategy of Polish émigrés. The research covers the analysis of factors that shaped the nature of the struggle for Poland's political independence abroad, among them, the Cold War between East and West and European integration. The nature of the sources used, mainly materials highlighting the life of the National Party in emigration, narrows the content of the research objective to the area of political thought of the legalistic camp; its leaders unanimously supported the strategy of regaining full sovereignty. The results of the research justify the conclusion that the idea "full sovereignty" laid the foundations of the information campaign launched immediately after WW2 and aimed to galvanize the immigrant community into political action.

Keywords: political emigre circles; Polish politics; sovereignty; European integration 